University at Buffalo School of Law

Digital Commons @ University at Buffalo School of Law

\title{
Bureaucratic Speech: Language Choice and Democratic Identity in the Taipei Bureaucracy
}

Anya Bernstein

University at Buffalo School of Law

Follow this and additional works at: https://digitalcommons.law.buffalo.edu/journal_articles

Part of the Law and Politics Commons

\section{Recommended Citation}

Anya Bernstein, Bureaucratic Speech: Language Choice and Democratic Identity in the Taipei Bureaucracy, PoLAR, May 2017, at 28.

C) ${ }_{\text {COPYRIGHT }}^{\text {N }}$

This Article is brought to you for free and open access by the Faculty Scholarship at Digital Commons @ University at Buffalo School of Law. It has been accepted for inclusion in Journal Articles by an authorized administrator of Digital Commons @ University at Buffalo School of Law. For more information, please contact lawscholar@buffalo.edu. 
Anya Bernstein

SUNY Buffalo Law School

\section{Bureaucratic Speech: Language Choice and Democratic Identity in the Taipei Bureaucracy}

This article illuminates the social nature of bureaucratic practice by analyzing the everyday speech of bureaucrats in a polyglossic society. My ethnographic analysis shows how Taipei city government administrators mobilize ideologies associated with Taiwan's two primary languages, and stereotypes associated with bureaucracy, to undermine both. Instead, they present themselves as a postethnonational and postbureaucratic avant-garde of their new democracy. In doing so, they draw on local values and tropes of legitimation, which place a premium on the personalistic relations and social imbrication of government actorsrelations that democracy, for all its potential to spawn dangerous chaos, is seen to facilitate. They represent their government employer not by claiming a superordinate status for it but by situating it as one participant within a complex of institutions, networks, and values. In illuminating both the internally and the externally social nature of government bureaucracy, I highlight the creative and progressive possibilities hidden within the drab government office. [bureaucracy, democracy, code switching, Taiwan]

"We rarely get so many community residents at a meeting," said the administrator in charge to the packed room, "so we can tell that the residents are very earnest and concerned." Leaders of the Dali Street Cultural Association, a community activist group from a poor Taipei neighborhood, sat around the huge table with numerous city government department representatives. ${ }^{1}$ The rest of us - around fifteen Cultural Association members-crammed into the narrow passages left around the table or hopped up onto the windowsills. We were there to discuss constructing a parking garage under a neighborhood park.

The administrator's gentle speaking style and little smile struck me as a bit condescending - a pat on the head from an indulgent teacher. It turned out, though, that I was the only one who felt so. Unlike me, other Cultural Association members already knew Mr. Wei from over a decade of activism, starting with their demand for that neighborhood park-no small request in one of the most densely populated areas of one of the world's most densely populated cities. ${ }^{2}$ Their acquaintance continued with subsequent protests, ceremonies, celebrations, and projects, like this parking garage plan, which had already dragged on for five years. ${ }^{3}$ They had interacted with Mr. Wei at every step on his path to a high position in the Bureau of Urban Development. Every Cultural Association member I talked to afterward agreed: he was forthcoming and easy to get along with (hao xiangchu 好相除 [good to encounter]), and had great speaking and negotiation skills (koucai 口才 [mouth talent]). And after all, the point of having so many Cultural Association members there - the point of announcing it at the monthly meeting, of the reminder phone calls, of the group subway trip to city hall—was to demonstrate the residents' earnest concern. ${ }^{4}$ Mr. Wei was indicating that the point had been taken.

Not all administrators were so good to encounter. As the association's community planner-an urban designer working for minimal pay on government-funded 
contracts-informally presented his proposal, a young administrator noted in perfect bureaucratese that the planner's fiscal estimates were idealistic. Insofar as no exact assessment of the projected expenditures necessitated by the parking lot had been provided, the young man's department would be unable to comment on the proposal at this time. His speech used the sharp side of etiquette: formal, meticulously polite, and cutting as a knife. The planner, face reddening, responded in less meticulous tones that parking lots were not his specialty and that he was expecting the government's assistance. The exchange continued for a few more rounds. The administrator got increasingly formal and convoluted; the planner raised his voice, leaning forward slightly as though about to lunge.

Finally, Mr. Wei intervened: "You just need to give us an estimate," he said to the planner. Without disputing the need for fiscal forthrightness, he minimized the gravity of the situation. "Just call up your colleagues who built that parking lot for National Taiwan University." Up to this point, the meeting had been entirely in Mandarin. Mr. Wei continued in Mandarin, "You just need to ask them" — and then switched into Taiwanese- " "how much did it cost?' That's all." 5 The community planner straightened, lowered his voice, nodded; the younger administrator offered no more comments. Mr. Wei's code-switching utterance had defused and reoriented the conversation.

Like Mr. Wei's soft tone and slight smile, his code-switching intervention can inspire different interpretations. Was he expressing ethnic solidarity by slipping into dialect? Was he using a "strateg[y] of condescension" to disingenuously stoop to the Cultural Association's level (Bourdieu 1991, 68-69)? What roles and relations did his code switch invoke? How did it figure Mr. Wei and the government that employed him?

In this article, I use bilingual exchanges like Mr. Wei's efficacious utterance as a springboard to explore the complex social life of a Taiwanese bureaucracy: both the internal sociality of its everyday life and its external situation within a wider sphere of institutions, values, and networks. I hope to show that utterances such as Mr. Wei's instantiate an authentic participation in the social networks in which Taiwanese government authority is embedded - a sociality that forms an integral part of the production of legitimated, democratic governance in this environment.

Creative language choices revealed that the bureaucrats I studied were working out their new administrative roles and new relations with their publics. In this, I argue, they formed an unexpected avant-garde of democratic identity. Indeed, not only interactions with the public but also "backstage" interactions among bureaucrats were characterized by creative language choices that presented administrators as postdictatorial professionals at the vanguard of Taiwan's developing democracy.

My informants' creative language use illuminates a more human side to bureaucracy than anthropological narratives usually reveal and hints at a progressive potential within the drab government office. Bureaucrats' resourceful deployment of existing tropes to fashion new identities and interactional forms also suggests that government bureaucracy is a key site for understanding, as well as constructing, actually existing democracies.

\section{Bureaucracy, Democracy, and the Taipei Bureau of Urban Development}

Government bureaucracy is a somewhat unusual place to look for democratic vanguards. Bureaucracy has meant many things to many people, but it has rarely meant anything good. ${ }^{6}$ For some influential thinkers, bureaucracy instantiates the "abdication of [the] human initiative and judgment" that is necessary for real democratic politics (Pitkin 1998, 79). It dissipates the human ability to stand out into "a kind of no-man rule" (Arendt 1959, 37). On this view, bureaucracy's "conflation of politics with administration" obviates the 
possibility of real political participation by subsuming potentially political action under a systematic rationality that precludes human creativity (Honig 1993, 2). ${ }^{7}$

It is possible, however, that bureaucracies, like other social institutions, have no single transhistorical nature. Rather, they may be products of their time and place-albeit ones that bear some organizational similarities across times and places. As other scholars have suggested, foundational beginnings, agonistic contestation, and the willful shaping of efficiencies and rationalities into political arguments can take place in office buildings as well as anywhere else (Honig 1995, 2005; Markell 2006). Perhaps looking for, or assuming, bureaucracy's essential, enduring character is not the most fruitful way to study it. It may be more realistic to understand bureaucracy as a loosely defined organizational form that bears some similarities across times and places but is also locally integrated and culturally specific.

Much of that specificity rests on the fact that the bureaucratic "official has characteristics as a social being beyond those which the administrative code specifies" (Albrow 1970, 55). Going beyond the merely informal or corrupt, administrators' unofficial practices can be patterned in ways that form "new elements of the organization" (Blau 1963, 2-3). In other words, the state apparatus "is both a semi-autonomous field and one in which the social properties of state officials and civil servants, which are determined partly outside the state field, play a key role" (Steinmetz 2014, 1).

Until recently much of the best-known anthropological work on bureaucracy did not directly address administrators' practices or self-understandings. For example, Michael Herzfeld's (1992) well-known study of bureaucratic indifference draws its data not from actual bureaucrats but from others' representations of bureaucrats. Bureaucrat appears as a category of person, much like an ethnicity, about which Herzfeld's informants offer stereotypes. Similarly, Akhil Gupta "attempt[s] to do an ethnography of the state by examining ... discourses of corruption" $(1995,375)$, rather than by examining the practices or self-conceptions of state actors. Bureaucracy is thus often presented as an object of (negative) social commentary rather than a social field of its own.

The last decade, however, has seen a renewed interest in bureaucrats and their micropractices as objects of ethnographic study (Bernstein and Mertz 2011). Recent scholarship has looked at government policies as social forces that affect both their objects and their creators, and scholars have become increasingly interested in the interpenetration of government bureaucracies and the social worlds in which they function (Shore et al. 2011). Studies have shown how documents, information, ideas, and people move through government organizations, creating networks, identities, and values in ways that specify and expand Weber's (1978) foundational ideal type of rational administration (Cabot 2012; Hoag 2010; Hull 2012; Latour 2010).

As Matthew Hull writes, understanding bureaucracy involves "understand[ing] collectivization and individuation as simultaneous functions of the same bureaucratic process, taking neither the agency of the individual nor the organization as given" $(2012,129-130)$. In a similar way, a bureaucratic agency itself is constituted both by its own internal social relations and by its external relations to other institutions. These relations construct bureaucracy as a particular, separate field of social activity. However, they also integrate bureaucracy into a broader social world. Moreover, as Jessica Greenberg (2014) notes, a newly democratized state apparatus can offer a site for particularly creative forms of political action. As old political conventions and values are thrown into question with the advent of a new political system, participants may deploy existing tropes in new ways to "change the terms of politics" in ways that remain "socially resonant and historically meaningful" in their particular contexts (7). I build on such work to illuminate how administrators marshal 
cultural stereotypes to create something new: an agentive, individualized bureaucratic identity that embraces a particular local understanding of democratic legitimacy.

In doing so, I place bureaucracy squarely at the center of democracy-not because bureaucracy is necessarily democratic, of course, but because bureaucracy is necessary to any modern democracy. The Taipei Bureau of Urban Development, where I situate my ethnography, allows for an exploration of the social life of a democratic bureaucracy. As the city's primary administrators of urban space, bureau employees regularly interact with numerous publics, as well as with the elected legislators who control their budget and mayors who set their policy. They are the objects of public demands and imprecations. They initiate projects that require cooperation from private actors and other government agents. ${ }^{8}$ They also ameliorate disputes between the city council and the mayor-disputes that are themselves a recent epiphenomenon of multiparty, democratic elections. Bureau administrators are aware of the tension between their popular image as power-hogging tyrants and their everyday practices as implementers of Taiwan's new governmental system. Indeed, many office conversations revolve around that tension. For all these reasons, Bureau of Urban Development administrators form an integral part of the development of a specifically Taiwanese democratic bureaucracy.

Of course, the image I present is particular, as any ethnographic image must be. First, the office I describe is located in a city government. Its administrators likely have more regular interaction with broader swaths of the public than those working in the central government, and they may be more explicitly beholden to the legislature. At the same time, this city government is closely connected to the national one. Taipei is Taiwan's political, economic, and population center. The Taipei mayoralty is seen as a stepping-stone to national political positions (the last two presidents were first Taipei mayors), and the city bureaucracy is often a stop along a career path leading to the central government. This makes possible a level of integration beyond what one might expect in countries with a greater number of key cities. That means that the conduct and understandings of city government employees likely have implications beyond the city government. In a larger sense, of course, the Taipei municipal administration forms - both conceptually and organizationally—one part of the greater social structure that can be broadly described as "the state" (see Martin 2013, $617)$.

Second, many of the bureau's administrators would not claim to represent all Taiwanese bureaucrats. On the contrary, they often describe themselves as enthusiastic innovators, in contrast to other bureaucrats in other places and times. In some sense, this very contrast enabled my ethnography; the fact that the bureau leadership allowed a foreign researcher to participate in everyday administrative activities speaks to its openness. At the same time, given the regular personnel flow to the central government, these bureaucrats are good candidates for high-status central positions later in their careers. In other words, while they may be somewhat special, they are neither anomalous nor marginal.

Third, my ethnography reveals a way of bureaucratic being that is situated in the specific history, culture, and social structures of Taiwan. I would not claim that all bureaucracies are like the one I describe. Any theorization of bureaucracy, however, should be able to accommodate the kinds of social relations and values that my ethnography reveals. I hope that my discussion illuminates some creative possibilities within bureaucratic action that anthropological accounts often overlook.

\section{The Politics of Language Choice in Taiwanese Bureaucracies}

Mr. Wei's efficacious utterance, which started off this article, combined Taiwan's two primary languages. Taiwanese, the island's majority language, is a local version of the 
Southern Min dialect spoken in China's Fujian Province, from which migrants came to Taiwan from the seventeenth century until Japan colonized the island from 1895 to $1945 .{ }^{9}$ After World War II, the victorious Allies ended Japanese colonization. They gave control of the island to the Chinese Nationalist Party, or KMT (Guomindang 國民黨), which had been formed in China while Taiwan was under colonial rule and, by the 1940s, was recognized as China's governing power. The KMT took possession of Taiwan during the late stages of its civil war with the Chinese Communists. As the Communists took control of China in 1949, an estimated two million people, many associated with the KMT, fled to Taiwan.

Declaring the KMT the legitimate government of China in temporary exile, government discourse and practice largely ignored the island in favor of the mainland. For instance, an average of 85 percent of national expenditures went to national security in the first fifteen years of KMT rule, leaving little for nondefensive development (Gold 1986, 69; Huang 2005). After the bloody repression of a 1947 uprising, the KMT instituted martial law in 1949. Years of intensive persecution of local elites cemented an emerging distinction between those whose families came to Taiwan before Japanese colonialism began in 1895 and those who arrived during or after the Chinese Revolution, in the 1940s. ${ }^{10}$ This distinction between "Taiwanese" people and "Mainlanders" continues to be the island's most salient ethnicized difference (Kerr 1965; Phillips 2003).

As state violence receded, the two groups retained different residential patterns and different routes to success, with Taiwanese joining the "traditional" middle class of smallscale entrepreneurs, and with Mainlanders forming a "new" middle class employed in government and larger businesses, often connected to the KMT (Gates 1981, 273-80; Kuo 2000). The KMT made Mandarin Chinese the language of the state and the public sphere. ${ }^{11}$ This helped shut the local Taiwanese, who had grown up speaking Taiwanese and Japanese, out of positions of power. Schools taught students about China rather than Taiwan (Chun 1996; Heylen 2001), and children were beaten for speaking Taiwanese in school.

The distribution of language and power in the public sphere led to enduring conceptual linkages. In local language ideologies, Mandarin was connected to formal interactions, public and official sites, power, and status; while Taiwanese was linked to intimacy, small business, the home, disempowerment, and lack of status (Berg 1982, 1988; Huang 1988; Kubler 1985, 1988; Young et al. 1992). These conceptual associations remain prevalent in both scholarship and everyday conversation, even as the distribution of both languages and power have changed dramatically. ${ }^{12}$

State agencies started actively hiring Taiwanese people in the late 1970s. ${ }^{13}$ This localization (bentuhua 本土化 [this-land-ization]) was part of a long-term political transformation responding to both internal and external pressures. Domestically, the Taiwanese democracy movement became increasingly vocal in the late 1970s and 1980s. Internationally, the United Nations (in 1971) and United States (in 1978) officially recognized the People's Republic of China (PRC), withdrawing diplomatic recognition from Taiwan and the KMT's claim to be the legitimate government of China. This put pressure on the KMT party-state to differentiate itself from the PRC and demonstrate its democratic bona fides. The KMT lifted martial law in 1986-1987. It instituted multiparty popular elections at all levels of government in 1994 and in 2000 participated in its first peaceful transfer of power, to the previously oppositional Democratic Progressive Party (Minjindang 民進黨).

Through all this, democracy activism maintained a significant ethnonationalist aspect. By framing democratization as an ethnonational awakening and a demand for specifically ethnic equality, the movement both built on, and helped solidify, the terms of identity politics (Huang 1995; Rigger 1999). 
Members of the emerging opposition often pointedly spoke Taiwanese in public settings, strove to increase people's awareness of Taiwanese (rather than Chinese) history and culture, and generally tried to reverse the KMT-imposed value hierarchy, which valorized indexes of the mainland, like Mandarin. In keeping with this push, increasing avenues for popular participation in state institutions have gone hand in hand with the promotion of localism as both a goal of, and a legitimating basis for, political action (Bernstein 2006; Chuang 2005; Huang 1995). The history of Taiwan is now taught in schools, and Taiwanese is allowed in all settings, sometimes taught in schools, and often used in political proceedings. Indeed, politicians are now sure to be able to give at least a snippet of a speech in Taiwanese, lest they be accused of harboring a martial law mentality or "not loving Taiwan" (bu ai Taiwan 不愛台灣).

Decades of intermarriage and cohabitation, common education, and the integration of Taiwanese language into popular culture and Taiwanese people into government have left most of the country effectively bilingual. In my fieldwork, even Mandarin speakers who described themselves as incapable of speaking Taiwanese could communicate in it when called upon to do so. ${ }^{14}$ While ethnic background once structured educational and career opportunities, my interlocutors increasingly connected each language to particular activities more than to particular ethnicities.

Language ability was thus generally seen as fluid, something one could develop rather than something one was stuck with. ${ }^{15}$ For example, a Mainlander friend who had spent her adult life working in a big company where she spoke only her native Mandarin started to learn Taiwanese when she left her job to open her own pub. She had joined the ranks of small entrepreneurs, which made speaking Taiwanese appropriate. In this sense, Mandarin and Taiwanese may be in the process of becoming registers rather than dialects (Irvine 2001)—connected to social roles more than to ethnic identities.

The democracy movement fought structural inequalities between Taiwanese and Mainlanders; its success largely eliminated them. The unequal, repressive situation that formed the backdrop to calls for ethnonational awakening and empowerment has largely disappeared, replaced by ongoing debate about origins, traditions, and political definitions that increasingly focuses not on ethnicized distinctions at home but on Taiwan's seemingly irresolvable relationship to mainland China. ${ }^{16}$ Linguistically, this process has given rise to an everyday life where people habitually utilize a range of expressive possibilities.

Anthropologists often look for what Susan Gal calls "unauthorized vernacular forms" that "enact values ... [that] oppos[e] the dominant value" $(1987,638)$. However, in Taiwan's case, rather than inverting the old value hierarchy and placing Taiwanese in an authoritative position over Mandarin, the country's ongoing political transformation has resulted in a diffusion of authoritative values. That makes it difficult to assign either language a clear position in a political economy. Taiwan's linguistic arena is now characterized by the absence of a clear hierarchy through which to define "unauthorized," as against "dominant," forms.

In the city government, for example, functional bilingualism is both a widespread fact and effectively a job requirement. To pass the civil service exams needed to enter government employment, an applicant must have excellent Mandarin; Taiwanese is not technically required for government employment. Nevertheless, an inability to speak Taiwanese well is considered a professional impediment, because administrators are expected to accommodate the preferences of their nongovernmental interlocutors with respect to Mandarin and Taiwanese. ${ }^{17}$ 
Some commentators have felt that Taiwan's polyglossia "constantly creates the problem of what code to choose" (Berg 1988, 253). In contrast, my interlocutors seemed to see opportunities, not problems, in the range of expressive options available to them (Bakhtin 1982; Gal 2011; Woolard 1999). Moreover, the combination of universal bilingualism with a shared history of the politicization of language made language choice a key site for the construction of political identity. ${ }^{18}$

\section{Social Life in a Bureaucracy}

Like other parts of Taipei City Hall, the Bureau of Urban Development is usually abuzz. Administrators gather around desks and lean over the low barrier that separates the walkway from the office area to chat. Other people butt in good-naturedly, calling out questions, information, and playful insults across the open office space. There is almost constant over-the-barrier and across-the-room chatter. Every few weeks a colleague comes around to distribute little cakes-customary presents given by people who just got engaged, are about to get married, or have recently had a child (Adrian 2003; Wolf 1968). Such people are invariably subjected to teasing on the subject of their good fortune, usually followed by discussions of party venues, daycare options, the changing role of the daughter-in-law in Taiwanese society, or other relevant topics.

Other factors enhance office social integration. Many administrators graduate from a small number of feeder schools. ${ }^{19}$ These graduates often know, or know of, one another long before they come to the city government. Common school background carries great significance in Taiwan, where graduates of the same department refer to and sometimes even address one another with modified kinship terms,${ }^{20}$ and classmates are generally presumed to have close relations. ${ }^{21}$ New hires enter a flurry of social activity as their subsection head, section head, graduates of their university department, and other connected coworkers take turns inviting them out for lunch with groups of colleagues.

Most administrators are, in other words, visible and audible; and they tend to know one another's business. Groups of current and former coworkers sing karaoke together, go hiking together, know one another's families, visit each other on holidays. This is not exceptional. As my interlocutors across socioeconomic and educational groups confirmed, the interpenetration of social and professional lives is both widespread and assumed in Taiwan. In other words, administrators are not friends because they form an elite class but because they are coworkers, and coworkers, generally speaking, tend to be friends. The "backstage," or internal, social life of this bureaucracy was thus highly active.

In addition, administrators were visible and audible not just to one another, but also to members of the general public who came to the office looking for help. The Bureau of Urban Development was not designed for such interaction. It has no general reception area; its secretaries do not look up inquiringly when someone enters; there is no indication of which administrator works on which project. ${ }^{22}$ Nevertheless, members of the public find their way there all the time, stopping someone in the hall or sticking their heads over a barrier, calling out a question to whoever looks up. They then go from answer to answer until they find someone with relevant information, who will typically interrupt whatever he or she is doing to help them.

Social life in the Bureau of Urban Development, in other words, is packed. Moreover, administrators actively participate in the society they regulate. They are subject to the same trends, witness the same stereotypes, and hold the same widely shared social values as their nongovernmental neighbors. Administrators often took their constant interaction with one another and the public as opportunities for creative self-presentation, using language tropes and the stereotypes associated with them to fashion administrative identities that 
rejected those very stereotypes. Such usages also drew on multiple, simultaneous arenas of institutional belonging, presenting administrators as not only government actors but also as participants in a variety of social relations and institutions that endure over time. Acknowledging, even valorizing, both their professional status and their multiple institutional belonging was central to these administrators' self-construction as the nation's new democratic bureaucrats.

\section{Postethnonational Identities of Postbureaucratic Bureaucrats}

The city administrators I worked with identified the return of popular mayoral elections to Taipei in 1994 as the turning point for their profession (Bernstein 2008, 944). ${ }^{23}$ As an appointed official, one section head explained, "you don't care whether [the public] supports you, ${ }^{24}$ [but those who] depend on the public for votes ... have to listen to it." ${ }^{25}$

Mr. An, an administrator working on urban renewal in the Dali Street area, contrasted the two eras. Instead of staying in the office, Mr. An would stop by neighborhood gathering places - the benches around the local temple, the rice store, and the little triangle of trees next to the power station - to chat with people. This would not have been possible before elected mayors.

Before, the government decided for itself what people wanted: "The government has given you a park, what else do you want?" But we discovered that a lot of times, we'd put in a park and then nobody would use it. Because we hadn't asked people ... what they wanted from a park.

Although Mr. An was also the object of the Dali Street Cultural Association's demands, both he and Cultural Association members told me that neighborhood residents went to his wedding, ${ }^{26}$ and that after he had a child, some Dali Street "community moms" (shequ mama 社區媽媽) made him oily rice (youfan 油飯), the traditional dish celebrating a son's first month of life. Fellow administrators in the bureau's central office also spoke with admiration of Mr. An's work; he was described as a key figure in the revitalization of the city's old, poor, crowded core.

Note how the public's relations with bureaucratic administration are figured in Mr. An's description. While martial law separates state from society, democracy opens up the possibility of greater personal relations with the objects of regulation. Through this increasing interaction with specific publics, the administrator becomes implicated in new relationships that coexist with his obligations and loyalty to the government.

Within some conceptions of democratic values, such close relationships between bureaucrats and regulated parties could be described as corruption or capture. ${ }^{27}$ People I talked with in Taiwan-not just activists and administrators but also teachers, entrepreneurs, academics, office workers, culture industry participants, and other acquaintances-never described these things in that way. ${ }^{28}$ The increased connection of administrators with administered was universally described in positive terms. It enhanced the government's claim to legitimate power and ameliorated the potentially chaotic effects of democratic pluralism. ${ }^{29}$

As Jeffrey Martin has written, "Taiwan's historical transition to democracy valorized the cultural trope of particularism" - that is, biographically specific individual relations"as a defining quality of legitimate force" $(2013,639)$. Rather than corrupting or capturing Mr. An, his close social relations with the people under his regulatory purview enhanced his ability to perform the Janus-faced role of every administrator: representing his government to its people and his people to their government. 
Administrators were also attuned to the reputations they had to live down. My coworkers compared our department favorably to departments in other cities and other times, whose administrators were said to be more "bureaucratic" (guanliao 官僚), meaning lazy, obstructionist, and hierarchical; "harder" (ying 硬), meaning nitpicky and legalistic; and more “traditional" (chuantong 傳統), meaning corrupt. The need to show the public that the department had moved beyond these martial-law-era traits came up regularly in discussions of policy implementation, which was universally understood to require negotiation and consensus-creation (Bernstein 2008).

For example, Mr. Ke, a section head, explained how he had convinced a particularly intransigent group of landowners to negotiate rezoning their area: "Bureaucrats all used to take money, want to eat, want to drink," he explained. When he and a subordinate first met with these landowners, "they invited us to eat-we ate simple lunch boxes. They invited us to drink-we drank water. Do you know how moved they were? They'd never seen bureaucrats like us. So after that they felt bad fighting with us." ${ }^{30}$ Choosing a brown-bag lunch with water over a banquet with alcohol differentiated these administrators from their martial law predecessors in ways that made negotiation, and therefore policy implementation, possible.

Stereotypes also fed the pool of inspiration for the office's ubiquitous self-mocking humor. After shadowing one gregarious, devoted administrator for several days, I asked him how it felt to be free of me. "I've already cussed out a bunch of the public,"31 he replied gleefully, as though it had only been my presence that had inhibited his normal bureaucratic arrogance. Another time, when I expressed surprise that my coworkers did not know the English word "bribe," one administrator replied with mock gravity, in English: "That is because when we take bribes, we do not speak English." The negative attributes commonly attributed to bureaucrats were thus ever present as a point of contrast: something to define oneself in opposition to, something to riff off in service of a joke.

Within this context, the universal availability of both languages, and the widely held language ideology linking Mandarin with officialdom and Taiwanese with intimacy, gave administrators a flexible tool for nuanced self-expression through which to contrast themselves from undesirable stereotypes. It allowed for moments of personal, interlocutorspecific footing in otherwise standard interactions, as when a senior official chairing a meeting, without appearing to interrupt a participant who was addressing her in Mandarin, called out to a latecomer in Taiwanese, "Come, come, come, sit here, sit here!"32 This bilingual byplay (Goffman 1981) - side conversations not perceived to interrupt the primary goings-on - allowed her to occupy simultaneously a position of formality (with respect to the administrator speaking Mandarin) and one of informality (with respect to the latecomer). Similarly, administrators often called others to shared office telephones using Taiwanese nicknames, ${ }^{33}$ acknowledging one another's everyday selves even as they conducted government business.

Administrators also often used different languages to contrast causes or initial events with effects or subsequent events in ways that highlighted distinctions between the speaker and others. For example, Ms. Gu, a midlevel administrator, delivered a diatribe to some coworkers about administrators from another department. It is not that they had worse training, she explained in Mandarin, it is just that they did not think broadly or comprehensively: "If you say one, they can't say two." ${ }^{44}$ They were used to simply doing what they are told. She began another explanation in Mandarin: "If the [supervisor] isn't there, the project just"—and concluded in Taiwanese- "goes on by itself." Again starting in Mandarin: "There's no change, and then it just" — and again concluding in Taiwanese—-dies." 35 
In this typical code-switch pattern, one language emphasized the results of conditions expressed in the other.

Ms. Gu was herself a native Taiwanese speaker who spoke a highly Taiwanese-inflected Mandarin. In this example, though, she presented the undesired result-projects running rudderless into the ground-in Taiwanese. The Mandarin-Taiwanese contrast, in other words, did not express her sense of ethnic differentiation from the people she described. It expressed a professional distance between her breed of active, thoughtful bureaucrat and those who conformed to negative stereotypes. Ms. Gu wrapped up her diatribe by using this same resultative code switch for a modest proposal that drew uproarious laughter: "First," in formal, pretentiously correct Mandarin, "send out invitations and officially invite everyone to come [to a meeting], well and then"-in Taiwanese-"kill them all." ${ }^{36}$

To similar effect, administrators used code switches to contrast their own narrated speech from that of others in the narration. For instance, Chuanzong, a low-level administrator tasked with ensuring that another department received some money that had mistakenly been sent to the Bureau of Urban Development, recounted his experience to colleagues. He began in Mandarin: "I contacted the accountant, asked how to fix [this]." ${ }^{37}$ Framing the accountant's response in Mandarin, he continued, "Well, the accountant said ..." Chuanzong then switched to Taiwanese to voice that response-“"Well, I don't know."”38 He returned to Mandarin for indirect reported speech-"[The accountant] told me to contact the section head"39 — and again he framed the speech in Mandarin. "Well, the section head said"-but again gave the direct reported speech in Taiwanese-“"Well, I don't know."”40 Chuanzong continued with this contrastive style throughout his narration of his long (and increasingly loud) telephone conversation, during which he had been transferred up and down a department whose employees seemed bafflingly uninterested in recovering its money. He used Mandarin for his own narrative and utterances but Taiwanese for the utterances of his interlocutors.

Chuanzong used the contrast between Mandarin and Taiwanese as a metapragmatic framing device, a quotation mark setting off others' utterances from his own voice. Far from an iconic representation, this was a stylistic choice: in fact, his interlocutors had also spoken Mandarin. The contrast between the languages gave him an understood, but unstated, way to distinguish himself from the kind of bureaucrats he had found on the other end of the line: people who did not care about getting things done but only wanted to make complications go away. Chuanzong did not draw on associations of Mandarin with formality and Taiwanese with informality; his particular frustration did not revolve around that contrast. Rather, his language choice allowed for a lively narrative style that distinguished between different kinds of equally formal behavior, highlighting the absurdity of the situation in a way his chuckling audience clearly appreciated.

The availability of different languages and stereotypes gave administrators a way to enact differentiated personalities that exceeded their job descriptions, allowing them to occupy variegated social roles. For instance, one rather serious male administrator once asked his colleague a perfectly normal question: "When is your meeting?" He did so using a sing-song voice, with a slow cadence and exaggerated tones, perfectly mimicking a style associated with children, cartoons, and sajiao 撒娇—a hyperfeminized, pouty affectation popular among young women speaking to intimates (example 1). His addressee, a jolly father of two, imitated his little-girl cuteness in response. The meeting set for that afternoon had been rescheduled for the following day. To make the first line of his response rhyme with the first line of the question, he made it comically ungrammatical-though still perfectly comprehensible (example 2). 
1. A-cho! A-cho!

[Taiwanese-derived nickname]

Li siammi sizun beh khuihoe?

You what time will meet?

(A-cho! A-cho! When is your meeting?)

2. E-bo! E-bo!

Afternoon! Afternoon!

Bo khuihoe ah, minachai chia u.

no meet PERF, tomorrow only have.

(In the afternoon! In the afternoon!)

(There's no meeting anymore, not until tomorrow.)

These speakers subtly manipulated everyday office interactions to show that they were youthful, lively, popularly-cultured guys, not reducible to interchangeable cogs in a bureaucratic machine. Administrators often slipped into this kind of play-acting, which drew on the idealized speech forms of children and intimate relationships, often depicted on television, to invoke the informality associated with Taiwanese. More than that, it drew participants into a mutually constructed scene, an interlocutor-specific interactional alternative to the conventional information exchange that office life often necessitates. Administrators thus mobilized commonly recognized stereotypes to present themselves - and to recognize one another-as individuals who exceeded stereotypes.

In contrast to the monologic drone often attributed to government employees (Errington 1995), administrators in the Taipei city government creatively used language contrast and stereotypy as tools for constructing new ways of being appropriate to their new government. Popular language ideologies continue to associate Mandarin with formality and the state, and Taiwanese with informality and the intimate. Administrators drew on these associations to inject formal, governmental situations with elements of intimacy and individuality, using stereotypes of language speakers to undermine stereotypes of haughty, distant, and corrupt bureaucrats. Their use of expectations, jokes, byplay, and role-play instantiated their common construction of what might be called a postbureaucratic professional identity, which would balance their role in the bureaucracy with their membership in a democracy, and incorporate the densely social and intensely personal nature of bureaucratic life.

\section{Language Choice and Multiple Network Construction}

The code switching styles described above valorized both administrators' professionalism and their embeddedness in institutions, networks, and relations that exceeded the city government. Such code-switching intimacies, moreover, were not reserved for "backstage" relations among administrators. They extended to "onstage" interactions with the public. In this context, government action acknowledged as legitimate by both participants and broader publics did not eschew personalistic relations; it was based on, and depended on, them. It was through developing long-term affective relations with residents that Mr. An gained the trust of local activists and urban administrators alike. It was by demonstrating his heartfelt earnestness and uprightness that $\mathrm{Mr}$. $\mathrm{Ke}$ - the section head who refused banquets and alcohol—brought local landlords to the negotiating table. It was in enacting multidirectional solidarity that Mr. Wei managed the conflict that started off this article.

I want to return to Mr. Wei's code switch now, to consider the different interpretations it gives rise to and their implications for the position of city government bureaucrats within their larger social surround. Recall that Mr. Wei said in Mandarin, "You just need to 
give us an estimate. Just call up your colleagues who built that parking lot for National Taiwan University and ask them. You just need to ask them"- and here he switched into Taiwanese-_"'How much did it cost?' That's all."

By describing the situation in Mandarin but giving an imaginary quotation in Taiwanese, Mr. Wei used the common trope, described above, of framing hypothetical speech in one language and then voicing it in another. He minimized the issue's importance by using “just" ( $z h i$ 只) ("You just need to ask them"). He then summed up the situation with "that's all" (soah soah khi), an expression that appears at the end of a suggestion to convey an easy finality to a potentially difficult decision. It has a similar emotional impact to American English "forget about it" or "who cares?," though it plays a different grammatical role. Although not slang, it is usually used among familiars. In the typical code-switching pattern, Mr. Wei might have used Taiwanese to report the community planner's imagined speech, then expressed his own evaluation that this was "not a big deal" with the parallel Mandarin term suanle 算了. Instead, he stayed in Taiwanese, completing one of the very few non-Mandarin utterances used in the meeting.

One traditional way to explain the efficacy of Mr. Wei's utterance is to look at the ethnic associations of the languages in use. Local language ideologies continue to link Mandarin to Mainlanders, and Taiwanese language to ethnically Taiwanese people (Tu 1996). Perhaps Mr. Wei was expressing ethnic solidarity with his interlocutors. In reality, though, not only were Mr. Wei and the community planner ethnically Taiwanese native speakers but so also was almost everyone else in the room, including most of the administrators. ${ }^{41}$ Mr. Wei's intervention is thus difficult to read as invoking ethnicized groupness.

From another perspective, Mr. Wei's dip into Taiwanese recalls Bourdieu's dialectspeaking Béarnais mayor. In what Bourdieu calls a "strateg[y] of condescension," the mayor appears to temporarily abdicate his authoritative position by deigning to use the local dialect in a speech (1991, 68-69). Garnering public praise for using the dialect instead of standard French, the mayor sneakily enhances his position by appearing to degrade it; using the dialect, after all, does not change the fact of the mayor's power or his role as representative of the very authority that renders French standard.

As Bourdieu notes, the efficaciousness of a strategy of condescension depends on institutional conditions: a strategy of condescension requires a position of superiority from which to condescend. This is, indeed, how the speech of government employees is often presented (Errington 1995): they animate government utterances unto their passively receiving, if resentful, populace. If Mr. Wei's speech primarily indexed participants' relative positions within the bureaucracy, then his use of unofficial language in an official setting would fit the bill perfectly. Deputy Chief Engineer Wei had, by far, the highest bureaucratic status of anyone in the room. His code switch appeared to bring him closer to people outside - and implicitly below - the bureaucratic hierarchy, gracing them with the legitimation vested in him to convey while maintaining his authority over them, even sneakily enhancing it by enforcing a much-valued consensus.

It is not obvious, however, that city government administrators held the kind of institutional power that would give them a secure place from which to condescend. My coworkers never talked about simply enforcing the law or implementing government policy. Through expressions of earnest concern, frequent social interactions, and practical demonstrations of solidarity, they put considerable effort into convincing people that the government they represented was worthy of respect and cooperation (Bernstein 2008). This reciprocal dependence of government institutions and civil society groups is not unique; as Patchen Markell has written, the unidirectional flow of speech and recognition is one way that state 
institutions appear to set the terms of recognition while obscuring the state's own reciprocal need for recognition from the people under its purview $(2003,30)$.

In Taiwan's new democratic order, civil society groups do depend on the government for recognition and funding. However, they also exert influence through things like organized demands bolstered by a decades-long rhetoric valorizing the "local" (Chuang 2004, 2005; Huang 2005) and a vibrant, ongoing discussion of the nature of democracy, all undergirded by savvy media use. ${ }^{42}$ Moreover, as discussed above, long-term, affective, interpersonal relations lay at the heart of legitimated government authority. From this perspective, Mr. Wei's speech indexed not a predictable institutional power over extrainstitutional actors but a larger social sphere that incorporates the state as one of a number of institutions striving for validation. In that sense, one might see Mr. Wei's speech as another kind of strategy: not of condescension but of legitimation.

Moreover, the bureaucratic hierarchy in which Mr. Wei held a high position was not the only politically efficacious institution in the room. The Dali Street Cultural Association had succeeded in pushing through many of its demands on the city government. ${ }^{43}$ Part of this success came from the group's ability to mobilize broad social networks. Despite their low socioeconomic status, residents-like many people-were closely tied to elected government officials. In Taiwan's highly personalistic electoral system, individual voters are often connected to both municipal and national representatives by relatively short chains of personal relations, often mediated through thiau-ah kha, a Taiwanese word that translates as "support post." These vote-gatherers use affective relations and skillful speech (as well as, sometimes, monetary incentives) to persuade others to vote for their candidates (Lin 1996; Moon 1998; Rigger 1999). ${ }^{44}$

Several Dali Street Cultural Association members had close relations with city and national legislators. At least one member acted as a vote-gatherer for an active, wellknown city councilor. By the logic of the power of the purse- the city council sets the city administration's budget - this translated into a certain influence on the city government. Moreover, one of the country's three main newspapers is headquartered in the neighborhood, giving the Cultural Association a reliable media platform.

Such social skills and ties, reminiscent of those required of small-scale entrepreneurs (Greenhalgh 1984, 1995; Hamilton and Kao 1990), are crucial for political activists in Taiwan's highly personalized political world (Chuang 2004, 2005; Weller 1999). It is widely agreed both within and without the city government, for example, that the Dali Street Cultural Association played an important part in defeating then-mayor Chen Shui-bian's reelection bid in 1998. The neighborhood leaned heavily toward Chen's Democratic Progressive Party (DPP). When the KMT candidate, Ma Ying-jeou, showed more interest in the Cultural Association's plans, however, members encouraged other residents to vote for him instead, and he carried the otherwise reliably DPP neighborhood. As one Cultural Association member told me with a chuckle, "We're very famous in the city government." 45

Acknowledging these multiple paths to power opens another vantage on Mr. Wei's Taiwanese code switch, which indexed his position in a social world populated by people with different forms of, and routes to, sociopolitical efficacy. As much as his use of Taiwanese may have served to enhance his power through condescension, it also acknowledged that his was not the only power in the room. Perhaps more than condescension, then, it was a strategy of concession.

This meeting, moreover, was merely one step in a long dance. Cultural Association members had gotten to know Mr. Wei over years of engagement with the city government. Although his administrative position had changed several times, his personality was seen 
as stable. He was known as a sympathetic, helpful person in a cultural context in which formal, rule-bound, standardized relationships are less valued than informal, customary, and particularized ones (Martin 2013; Winn 1994). Mr. Wei's authority rested, then, partly on acquaintance, biographic background, and individual personality traits.

When Mr. Wei summed up his suggestion with the no-big-deal Taiwanese modal soah soah khi ("that's all"), he negated the younger administrator's suggestion that the discussion could not go forward, disrupting his ying (unyielding) and guanliao (bureaucratic) performance. He invoked instead an ethical universe with values focused not on legality or accuracy but on mutual aid and its concomitant mutual obligation - sentiments seen as properly characterizing long-term relationships of all sorts in Taiwan (Deglopper 1995; Martin 2007). Making good on his positive reputation, Mr. Wei might be described as bolstering his ability to enact his individual self in a government-based interaction through a strategy of individuation.

Condescension, legitimation, concession, individuation: all are plausible readings of the import of Mr. Wei's Taiwanese use. They also may all have a place in his single utterance. The complex matrix of interactive institutions, social values, and personal relationships within which Mr. Wei spoke undermines any claim to a single correct interpretation. As a city administrator, he represented the government charged with managing his interlocutors at the same time as he needed their cooperation, was subject to their power, and was embedded in long-term personal relationships with them. Mr. Wei's utterance thus indexed multiple, related constellations of social roles and relationships. These included, at the least, the nexus of city administrative units charged with managing both the spaces of the city and the relations of the city's people with its government; his own self-presentation as a helpful and approachable administrator; the widespread social ideal of consensus; and his personal ongoing relations with Dali Street neighborhood residents.

In short, his utterance presented him not as a unidimensional bureaucrat but as a multidimensional individual embedded in numerous institutions and relations. Far from imposing a single import on his words, his bureaucratic position implicated him in multiple subject positions that lent his speech an intrinsic multivalence. This multivalent, social, and affective self-presentation, I have argued, is a hallmark of Taipei administrators' developing identity as democratic bureaucrats.

\section{Conclusions and Implications}

Using the lens of code switching and other forms of bureaucratic speech, I have presented Taipei administrators as self-consciously embedded in multiple sociopolitical institutions and networks. I show how they creatively invoke interpersonal relationships, longstanding values and loyalties, and cultural understandings and stereotypes to construct an emerging identity of a bureaucrat suited to a specifically Taiwanese democracy.

My interlocutors drew on language ideologies and common stereotypes, as well as a little-noted local tendency to connect languages to situations rather than to ethnicities. They deployed these tools to distance themselves from common negative images of administrators as hard, bureaucratic, and traditional-that is, legalistic, hierarchical, and corrupt-presenting themselves instead as flexible, personable, and earnest. Language choice, I have claimed, provides a particularly fruitful lens through which to view these practices because of the deep and well-known imbrication of political rule and political ideology with language use over Taiwan's last century.

The way that community activists, landowners, and sometimes-contentious interlocutors reacted to such displays indicates that such self-presentation was often successful. Lacking 
the martial-law-era ability to simply impose policy on a passive public, these administrators were often effective at a more complex, democratic style of authority. Externally, they forged long-term interpersonal relations with the private parties under their purview, enticing and cajoling them into negotiating over local projects and government initiatives. Internally, they supported one another in constructing postbureaucratic professional identities that reflected values they shared with their publics.

As I have suggested, the particular kind of bureaucratic identity I found in Taipei City Hall departed in important ways from the Weberian ideal-type and many scholarly presentations. Neither government employees nor publics, for example, viewed the proper role of administrators as defined by their job descriptions. Nor did anyone suggest that administrators were, or should be, interchangeable based on their institutional positions. On the contrary, personal characteristics and personalistic relationships were central aspects of how administrators were able to get things done; and they were explicitly valued by both bureaucrats and the people they administered.

Relatedly, the idea that administrators should owe exclusive loyalty to the government that employed them was discursively tied to a martial-law-era approach to governance. Democratized city bureaucrats, in contrast, were assumed to be, and supposed to be, embedded in multiple social spheres that shared claims on their sense of obligation. In this sense, the Taipei bureaucrats I worked with were adjusting to emerging ideas of government legitimacy based squarely in Taiwan's particular history of democratization.

In his synthesis of research on modernist knowledge production, James Scott (1998) explains how state bureaucracies often simplify the matters they oversee, making them more manageable in the short run by obscuring key factors that ultimately defeat management. By unpacking bureaucrats' complex speech choices, I have tried to avoid simplifying bureaucracy itself. I treat government employees as complexly motivated individuals implicated in multiple institutional roles and social relations. I present their language choices as more than merely assertions of institutional authority or ethnic identity. Although ethnic identity is a highly salient form of belonging, it does not suffice to explain the common linguistic choices of Taipei administrators; that requires a more complex description that is populated by more participants. Relatedly, bureaucratic speech is easy to present as a statement of governments' superiority over other social institutions. Again, this highly visible form of belonging does not explain administrators' actual, complex and creative, language choices.

Instead of looking for one central synapse that would express governmental power and explain administrators' language choices, I suggest that understanding the situations I present requires viewing these bureaucrats as embedded in multiple, interacting, social spheres. This complicated, multiperspectival view, I argue, has benefits for the study of bureaucracy. It allows for an analysis of government action that does not rely on categories created or recognized by that very government. For example, it does not peg an understanding of language choice on politicized categories of ethnicized belonging or government employment. Rather, it allows commentators to see how such categories are mobilized at some points but undermined at others. It also encourages attention to the situations in which such categories recede in relevance or become fuzzy around the edges.

Relatedly, this approach presents government bureaucracy, much like other social institutions, as both a fully integrated part of society and a somewhat distinctive sphere of action and relation. In that sense, this multiperspectival approach helps situate bureaucracy as an always localized phenomenon; that is, a loose organizational form that maintains certain similarities over times and places, but is always situated within, and reflective of, very particular sociocultural contexts and historical trajectories, with their attendant values, beliefs, and practices. 
Perhaps most satisfyingly, my approach allows scholars to see, and relate to, bureaucrats as full participants in their society, illuminating the possibility of creative and progressive action even within seemingly drab and dehumanized settings. I would not claim that all bureaucracies resemble the one I worked in. I hope, however, that I have shown that a complete understanding of bureaucracy must be able to accommodate the patterns I describe as a potential, not anomalous, aspect of bureaucratic functioning.

\section{Notes}

This article benefited greatly from conversations with Nicholas Day, David Engel, Jessica Greenberg, and Jeffrey Martin, as well as from extremely helpful comments from anonymous reviewers. I am grateful for the Fulbright-Hays fellowship that supported this research and for the Blakemore fellowship that funded my language coursework at the International Chinese Language Program.

1. This article is based on ethnographic fieldwork. I spent roughly one year living in the Dali Street neighborhood, both working and socializing with Dali Street Cultural Association members. I then spent roughly nine months working with administrators in the Taipei City Government Bureau of Urban Development. For the first three of those months, I undertook interviews and conversations with administrators at the bureau's urban renewal office outpost near Dali Street. I then spent six months as a full-time volunteer in the bureau's central city hall office, where I worked as the department's English language consultant. I spent my days interacting with administrators: I talked with them; sat in on their meetings with other government employees, consultants, and members of the public; and accompanied them on inspections, offsite meetings, lunch outings, weekend hikes, dinners, and other activities. I observed hundreds of meetings and less formal interactions, and had hundreds of conversations with administrators from across the bureau, as well as from other departments. I also recorded roughly thirty hours of open-ended, semistructured interviews with administrators at every level of the organization, from bureau head to low-level functionary. Like many ethnographers, though, I found that my primary material came not from interviews, which record the stories people told when asked to tell stories, but rather from the off-hand remarks, unreflective answers, and real-time commentaries-to me and to others-that characterize the bureau's lively social life. Except for an English language practice lunch I headed a few times, all these interactions took place in some combination of Mandarin Chinese and Taiwanese. (Like other educated Taiwanese speakers, administrators also occasionally interject English words into Chinese speech.) I render Mandarin quotations in pinyin transliteration and Chinese characters; Taiwanese quotations in Missionary Romanization (Taiwanese does not have standardized characters). Where I do not have exact wording, I give the gist of an utterance in English translation only. I use pseudonyms for my interlocutors.

2. Taipei's official population density hovers above 9,500 people per square kilometer. (For comparison, New York City houses roughly 1,800 people per square kilometer). Because almost a third of the city's area comprises a national park, and because many people do not change their official registration to Taipei when they move from other parts of Taiwan, the lived density is even higher.

3. For more on this neighborhood and its Cultural Association, see Bernstein (2006), Chen (2002), Chen (2000). 
4. For more on the importance of earnest concern to political action in Taiwan, see Bernstein (2006), Martin (2007).

5. “Ni zhiyao gen ta jiang 你只要跟他講, 'Ying guache chi?' soahsoahkhi."

6. For social etymologies that survey the term's range of meanings, see Albrow (1970) and Kafka (2012). Another Kafka ([1925] 1998a, [1926] 1998b), of course, provides some of the most enduring images of bureaucracy.

7. McCormick (1997) discusses a similar view in Carl Schmitt ([1922] 1985a; [1926] 1985b; [1932] 2004). Although Max Weber's (1978) classic exposition presents bureaucracy in a more positive light, it also presents a rather mechanistic, predictable organization subsuming the characteristics of individuals.

8. For the importance of cooperation and consensus to political action in Taiwan, see Bernstein (2008). In a related vein, Jeffrey Martin describes one aspect of political legitimation in Taiwan as "self-consciously ... organized by values of intimate solidarity defined in explicit opposition to abstract legal principles" $(2013,616)$. Martin found this intimate legitimation in the context of police authority; I found something similar among administrators.

9. This language is sometimes known as Taiyü 台語 or Taiwanhua 台灣話 (Taiwanese language), sometimes as Minnanyü 閩南語 (Southern Min language). A speaker's choice of what to call the language itself can suggest political opinions with respect to Taiwan's relationship to mainland China. For example, calling the local language Southern Min can signal the view that Taiwan is, politically or culturally, a part of China, while calling it Taiwanese can indicate the attribution of cultural uniqueness and independence to the island. Similarly, whether Taiwanese is a "language" or a "dialect" is a politically fraught issue. For more on Taiwan's colonial history, see Ka (1995) and Myers and Peattie (1984).

10. Those who came with the KMT and their descendants are often called "Mainlanders" in English (Waishengren 外省人; outside-the-province people in Mandarin). Descendants of pre-1895 migrants are often called "Taiwanese" in English (Benshengren 本省人; this-province people in Mandarin). The latter group comprises 84 percent to 85.5 percent of the island's population. This includes both people whose ancestors came from Fujian and the Hakka, a Chinese minority from provinces other than Fujian that is treated as a distinguishable subset of the local (bentu 本土 [this land]), non-Mainlander population. Hakka make up 10 percent to 12 percent of the population; Mainlanders 13 percent to 14 percent; and indigenous people 1.7 percent to 2 percent (Government Information Office 2003; Huang 1988).

11. Mandarin is usually called Guoyü 國語 (national language), and sometimes Huayü 華語 (Chinese language). It is mutually incomprehensible with Taiwanese. Mandarin on Taiwan has some local characteristics, but it is very similar to Mandarin in China (Putonghua 普通話 [common language]), and the two are completely mutually comprehensible.

12. Studies of language distribution and language ideology on Taiwan often suffer from what Judith Irvine has identified as a propensity to rely on concepts such as "social evaluation, attitudes, scales of prestige, ... schemes of values, [and] ... social identity ... as if they could be taken as obvious ... [and] needed no independent investigation" (2001, 24). 
13. This process, seen as an effort to head off mass disaffection, did not prevent regime change, but probably contributed to the continuing legitimacy of the KMT after democratization (Chun 2000).

14. I should note that my fieldwork, and most of my time, was spent in Taipei, which is known to be a heavily Mandarin-speaking area. In the south, many more people speak Taiwanese as a primary language. In my experience, however, many such people also can speak Mandarin if they need to.

15. This equanimous attitude toward language acquisition fits with Taiwan's generally multilingual culture. Everyone knows at least some people who speak or read more than two languages well, be it English, Japanese, Hakka, or one of the surviving indigenous languages. Many more people speak or read some of these languages to some lesser extent. The Taiwanese Internet, for example, is chock full of puns involving various combinations of Mandarin, Taiwanese, Japanese, and English, written in combinations of Chinese characters, Japanese syllables, Roman letters, Mandarin Phonetic Symbols, and numbers.

16. For more on the relation of internal and external identity in Taiwan, see Allen (2005); Bosco (1994); Chun (1996; 2000); Corcuffe (2002).

17. This expectation does not extend to Hakka or the indigenous languages.

18. To be clear, I do not claim that code switching is a sign of democracy in itself. Rather, it provides an avenue for the construction of democratic identities in Taiwan's particular sociopolitical trajectory; it is a tool available to people in Taiwan, which my interlocutors in the city government used in a particular way.

19. Many administrators are trained at National Taiwan University's Graduate Institute of Building and Planning, known for Marxist theoretical innovation and qualitative analysis, or at National Cheng-Kung University's Department of Urban Planning, known for rigorous practical training and quantitative approaches.

20. These terms combine the word for study (xue 學) with regular sibling terms, which specify gender and birth order, to indicate relative graduation order (e.g., younger brother in study; xuedi 學弟). Classmates are tongxue 同學 (togetherstudents).

21. For example, my landlady got nervous when a friend (pengyou 朋友) planned to stay with me, but when I mentioned that this friend was a college classmate (tongxue 同 學), she readily agreed - a classmate, she made clear, was a different story than a mere friend.

22. In contrast, the first floor of city hall holds a series of desks staffed by employees from each city department, who handle common administrative tasks.

23. Taipei elected its mayors from 1947 until 1967, when the central government began appointing mayors after a non-KMT candidate won a second term (Rigger 1999, 2001).

24. “Ta zhibuzhichi ni buguan 他支不支持你不管."

25. “kao minzhong de xuanpiao 靠民眾的選票 ... yao ting tade要聽他的."

26. Taiwanese weddings are huge affairs funded largely through monetary gifts from guests, and invitations are distributed broadly. Showing up is a way of supporting the couple's social status.

27. For an overview and critique of the concept of capture, see Novak (2013).

28. This attitude is likely not unique to Taiwan. Robert Kagan (2001) explains that the American view of cooperation and capture in the administrative state is anomalous (and inefficient). 
29. Someone from every social group I came in contact with in Taiwan told me that Taiwan was “too democratic” (tai minzhu 太民主). When pressed, people would generally explain this statement with references to a loss of consensus (gongshi 共 識) on public issues — a consensus those same people often admitted had been created through force under martial law - and a breakdown of social norms. As one activist put it when I asked her what she meant by it, "[People] even cuss out the president!" (“Dou ma zongtong ah 都罵總統啊”).

30. “Yiqian de guanyuan dou naqian, yao chi, yao he 以前的官員都拿錢, 要吃要喝.... Tamen qing women chifan, women chi biandang 他們請我們吃飯我們吃便當. Tamen qing women he dongxi, women he kaishui 他們請我們喝東西我們喝開水. Ni zhidao tamen duome gandong 你知道他們多麼感動? Conglai meiyou kandao xiang women zheyangzi de guanyuan從來沒有看到像我們這樣子的官員. Suoyi yihou tamen ye bijiao buhao yisi gen women chaojia 所以以後他們也比較不好意思跟我們吵架.”

31. "Wo yijing male haojige minzhong 我已經罵了好幾個民眾."

32. "Lai, lai, lai, che chia, che chia!"

33. Mandarin nicknames place lao 老 (old) or xiao 小 (young) before a family name; Taiwanese nicknames place the interjection "ah" before one syllable of a given name.

34. “Ni gen ta jiang yi, ta bu hui jiang er 你跟他講 ，他不會講 .”

35. “Guzhang yi bu zai zheige anzi jiu 股長 不 在這個案子就dit-dit dit-dit kia", meiyou bianhua 沒有變化, ah ranhou jiu 然後就 siki ah.”

36. “Xian fa gongwen zhengshi qing dajia lai 先發公文正式請大家來, ah ranhou 然 後... ho in si."

37. “Wo zhao kuaijishi wen, zenme chuli 我找會計師問怎麼處理."

38. “Ah kuaijishi shuo 會計師說, ah gua m-chai oh.”

39. “Jiao wo zhao kezhang 我找科長."

40. “Ah kezhang shuo 科長說, ah gua m-chai oh."

41. Two of the Cultural Association leaders were Hakka but spoke Taiwanese natively. Over the course of my fieldwork, I had enough interactions with most people in the room that day to know their ethnolinguistic heritages.

42. The success of the recent Sunflower Movement, in which student activists occupied the national legislature to protest the closed-door passage of a trade agreement with the PRC, exemplifies that conversation at the national level (Rowan 2015).

43. Such demands were often accompanied by widely publicized demonstrations as well as strategically organized festivals, in which public figures were put on the spot and asked to express support for local initiatives. For example, the Cultural Association organized a yearly Sugarcane Festival to commemorate the area's plantation history. During my fieldwork, the president, vice president, and mayor all appeared and made speeches at the festival.

44. Thiau-ah-kha "pull votes" (lapiao 拉票) for their preferred candidates by "chatting (tan 談)" with their plentiful acquaintances_- "chat" being preferred over "convince" (shuifu 說服), for these conversations among social equals (cf. Moon 1998). Unlike their closest American parallel, ward bosses, the thiau-ah-kha are not seen to control a voter's employment prospects but to connect constituents to elected officials who can then distribute favors. Such favors include things like pressuring city administrators to refrain from implementing city ordinances in ways that are disadvantageous for those constituents (something many of my coworkers complained of), as well as pressuring them to accede to constituents' affirmative demands for more services.

45. “Women zai shizhengfu hen youming 我們在市政府很有名.” 


\section{References Cited}

Adrian, Bonnie. 2003. Framing the Bride: Globalizing Beauty and Romance in Taiwan's Bridal Industry. Berkeley: University of California Press.

Albrow, Martin. 1970. Bureaucracy. New York: Praeger Publishers.

Allen, Joseph. 2005. "Mapping Taipei: Representation and Ideology, 1626-1945." Studies on Asia Series III 2 (2): 59-80.

Arendt, Hannah. 1959. The Human Condition: A Study of the Central Dilemmas Facing Modern Man. Garden City NY: Doubleday Anchor.

Bakhtin, Mikhail M. 1981. The Dialogic Imagination: Four Essays, edited by Michael Holquist. Translated by Michael Holquist and Caryl Emerson. Austin: University of Texas Press.

Berg, Marinus Elisa van den. 1988. “Taiwan's Sociolinguistic Setting.” In The Structure of Modern Taiwanese: A Modern Synthesis 現 台灣話研究論文集, edited by Robert L. Cheng and Shuanfan Huang, 243-58. Taipei: Crane Publishing.

- 1992. "Ethnolinguistic Identities and Accommodation Across Generations in Taiwan." Journal of Asian Pacific Communication 3 (1): 145-64.

Bernstein, Anya. 2006. "Parameters of Legitimation and the Environmental Future of a Taipei Neighborhood." In Echoes From the Poisoned Well: Global Memories of Environmental Injustice, edited by Sylvia Washington, Heather Goodall, and Paul Rosier, 311-30. Lanham, MD: Lexington.

. 2008. "The Social Life of Regulation in Taipei City Hall: The Role of Legality in the Administrative Bureaucracy." Law \& Social Inquiry 33 (4): 925-954.

, and Elizabeth Mertz. 2011. "Introduction Bureaucracy: Ethnography of the State in Everyday Life." PoLAR: Political and Legal Anthropology Review 34 (1): 6-10.

Bosco, Joseph. 1994. "The Emergence of a Taiwanese Popular Culture." In The Other Taiwan: 1945 to the Present, edited by Murray A. Rubinstein, 392-403. Armonk NY: M. E. Sharpe.

Bourdieu, Pierre. 1991. Language and Symbolic Power, edited by John B. Thompson. Translated by M. Adamson and G. Raymond. Cambridge, MA: Harvard University Press.

Blau, Peter M. 1963. The Dynamics of Bureaucracy: A Study of Interpersonal Relations in Two Government Agencies. Chicago: University of Chicago Press.

Cabot, Heath. 2012. "The Governance of Things: Documenting Limbo in the Greek Asylum Procedure.” PoLAR: Political and Legal Anthropology Review 35 (1): 11-29.

Chen, Dejun Vivian 陳德君. 2002. 危機與轉機：追蹤萬華大理街社區的空間實践 [The turning point of the spatial practice of Dali Street, Wanhua]. MA thesis, National Taiwan University.

Chen, Xingjun 陳幸均. 2000. 老市 心社區 空間實踐: 萬華大理街社區運動 個案 研究 [Community spatial practice in the old city center: A study of Wanhua District's Dali Street community movement]. MA thesis, National Taiwan University.

Chuang, Ya-Chung. 2004. "Democracy in Action: The Making of Social Movement Webs in Taiwan." Critique of Anthropology 24 (3): 235-55.

- 2005. "Place, Identity, and Social Movements: Shequ [Community] and Neighborhood Organizing in Taipei City." Positions East Asia Cultures Critique 13 (2): 379-410. 
Chun, Allen. 1996. "From Nationalism to Nationalizing: Cultural Imagination and State Formation in Post-War Taiwan." In Chinese Nationalism, edited by Jonathan Unger and Geremie Barmé, 126-47. Armonk, NY: M. E. Sharpe.

2000. 'Democracy as Hegemony, Globalization as Indigenization, Or the 'Culture' in Taiwanese National Politics.” In Taiwan in Perspective, edited by Wei-Chin Lee, 7-27. Leiden: Brill.

Corcuff, Stephane, ed. 2002. Memories of the Future: National Identity Issues and the Search for a New Taiwan. Armonk NY: M. E. Sharpe.

DeGlopper, Donald R. 1995. Lukang: Commerce and Community in a Chinese City. Albany: State University of New York Press.

Errington, Joseph. 1995. "State Speech for Peripheral Publics in Java." Pragmatics 5 (2): 213-24.

Gal, Susan. 1987. Codeswitching and Consciousness in the European Periphery. American Ethnologist 14(4):637-653.

- 2011. "Polyglot Nationalism. Alternative Perspectives on Language in 19th Century Hungary." Langage et société, no. 2, 31-54.

Gates, Hill. 1981. "Ethnicity and Social Class." In The Anthropology of Taiwanese Society, edited by Emily Martin Ahern and Hill Gates, 241-81. Stanford, CA: Stanford University Press.

Government Information Office. 2003. Taiwan Yearbook 2003. Taipei: Government Information Office, Republic of China.

Goffman, Erving. 1981. Forms of Talk. Philadelphia: University of Pennsylvania Press.

Gold, Thomas B. 1986. State and Society in the Taiwan Miracle. Armonk, NY: M. E. Sharpe.

Greenberg, Jessica. 2014. After the Revolution: Youth, Democracy, and the Politics of Disappointment in Serbia. Stanford, CA: Stanford University Press.

Greenhalgh, Susan. 1984. "Networks and Their Nodes: Urban Society on Taiwan." China Quarterly, no. 99, 529-52.

1995. "De-Orientalizing the Chinese Family Firm." American Ethnologist 21 (4): $746-75$.

Gupta, Akhil. 1995. "Blurred Boundaries: the Discourse of Corruption, the Culture of Politics, and the Imagined State." American Ethnologist 22(2):375-402.

Hamilton, Gary, and Cheng-shu Kao. 1990. "The Institutional Foundations of Chinese Business: The Family Firm in Taiwan." Comparative Social Research, no. 12, 135-51.

Herzfeld, Michael. 1992. The Social Production of Indifference: Exploring the Symbolic Roots of Western Bureaucracy. New York: Berg.

Heylen, Ann. 2001. "From Local to National History: Forces in the Institutionalization of a Taiwanese Historiography." China Perspectives (Hong Kong), no. 37, 39-51.

Hoag, Colin. 2010. "The Magic of the Populace: An Ethnography of Illegibility in the South African Immigration Bureaucracy." PoLAR: Political and Legal Anthropology Review 33 (1): 6-25.

Honig, Bonnie. 1993. Political Theory and the Displacement of Politics. Ithaca: Cornell University Press.

1995. "Toward an Agonistic Feminism: Hannah Arendt and the Politics of Identity." In Feminist Interpretations of Hannah Arendt, edited by Bonnie Honig, 215-35. University Park: Pennsylvania State University Press. 
2005. "Bound By Law? Alien Rights, Administrative Discretion, and the Politics of Technicality: Lessons From Louis Post and the First Red Scare." In The Limits of Law, edited by Austin Sarat, Lawrence Douglas, and Martha Merrill Umphrey, 209-45. Stanford, CA: Stanford University Press.

Huang, Liling 黃麗玲. 1995. 新國家建構 程 社區角色的轉變 - ‘生命共同體” 論 述分. [Transformation of the role of community in the process of establishing a new nation: An analysis of the discourse of Shengming Gongtongti [Communal Lifeworld]. MA thesis, National Taiwan University.

. 2005. "Urban Politics and Spatial Development: The Emergence of Participatory Planning in Taipei.” In Globalizing Taipei, edited by Reginald Kwok, 78-98. London: Routledge.

Huang, Shuanfan. 1988. "A Sociolinguistic Profile of Taipei." In The Structure of Modern Taiwanese: A Modern Synthesis 現 台灣話研究論文 集, edited by Robert L. Cheng and Shuanfan Huang, 301-31. Taipei: Crane Publishing.

Hull, Matthew S. 2012. Government of Paper: The Materiality of Bureaucracy in Urban Pakistan. Berkeley: University of California Press.

Irvine, Judith. 2001. "'Style' as Distinctiveness: The Culture and Ideology of Linguistic Differentiation." In Style and Sociolinguistic Variation, edited by Penelope Eckert and John R. Rickford, 22-43. Cambridge: Cambridge University Press.

Ka, Chih-ming. 1995. Japanese Colonialism in Taiwan: Land Tenure, Development, and Dependency, 1895-1945. Boulder, CO: Westview Press.

Kafka, Ben. 2012. The Demon of Writing: Powers and Failures of Paperwork. New York: Zone Books.

Kafka, Franz. (1925) 1998a. The Trial: A New Translation, Based on the Restored Text. Translated by Brean Mitchell. New York: Schocken Books.

- (1926) 1998b. The Castle: A New Translation, Based on the Restored Text. Translated byMark Harman. New York: Schocken Books.

Kagan, Robert A. 2001. Adversarial Legalism: The American Way of Law. Cambridge, MA: Harvard University Press.

Kerr, George H. 1965. Formosa Betrayed. Boston: Houghton Mifflin.

Kubler, Cornelius. 1985. The Development of Mandarin in Taiwan: A Case Study of Language Contact. Taipei: Student Book.

—. 1988. "Code-Switching Between Taiwanese and Mandarin in Taiwan." In The Structure of Modern Taiwanese: A Modern Synthesis 現 台灣話研究論文集, edited by Robert L. Cheng and Shuanfan Huang, 263-79. Taipei: Crane.

Kuo, Cheng-tian. 2000. "Taiwan's Distorted Democracy in Comparative Perspective." Journal of Asian and African Studies 35(1):85-111.

Latour, Bruno. 2010. The Making of Law: An Ethnography of the Conseil d'État. New York: Polity.

Lin, Jih-Wen. 1996. Consequences of the Single Non-Transferrable Voting Rule: Comparing the Japan and Taiwan Experiences. PhD thesis, University of California.

Markell, Patchen. 2006. "The Rule of the People: Arendt, Archê, and Democracy." American Political Science Review 100 (1): 1-14.

Martin, Jeffrey T. 2007. "A Reasonable Balance of Law and Sentiment: Social Order in Democratic Taiwan from the Policeman's Point of View." Law \& Society Review 41 (3): 665-97. 
2013. "Legitimate Force in a Particularistic Democracy: Street Police and Outlaw Legislators in the Republic of China on Taiwan." Law \& Social Inquiry 38 (3): 615-42.

McCormick, John P. 1997. Carl Schmitt's Critique of Liberalism: Against Politics as Technology. Cambridge: Cambridge University Press.

Moon, Eric P. 1998. "Democracy at the Grass Roots: Taiwan's 1998 Township Council and Neighourhood Chiefs Elections.” China Perspectives, no. 19, 22-43.

Myers, Ramon H., and Mark R. Peattie, eds. 1984. The Japanese Colonial Empire, 18951945. Princeton, NJ: Princeton University Press.

Novak, William. 2013. "A Revisionist History of Regulatory Capture." In Preventing Regulatory Capture: Special Interest Influence and How to Limit it, edited by Daniel Carpenter and David Moss, 25-48. Cambridge: Cambridge University Press.

Phillips, Steven E. 2003. Between Assimilation and Independence: The Taiwanese Encounter With Nationalist China, 1945-1950. Stanford, CA: Stanford University Press.

Pitkin, Hannah Fenichel. 1998. The Attack of the Blob: Hannah Arendt's Concept of the Social. Chicago: University of Chicago Press.

Rigger, Shelley. 1999. Politics in Taiwan: Voting for Democracy. London: Routledge.

- 2001. From Opposition to Power: Taiwan's Democratic Progressive Party. Boulder, CO: Lynne Rienner Publishers.

Rowan, Ian. 2015. “Inside Taiwan's Sunflower Movement: Twenty-Four Days in a StudentOccupied Parliament, and the Future of the Region." Journal of Asian Studies 74 (1): $1-15$.

Schmitt, Carl. (1922) 1985a. Political Theology: Four Chapters on the Concept of Sovereignty. Translated by George Schwab. Cambridge, MA: MIT Press.

- (1926) 1985b. The Crisis of Parliamentary Democracy. Translated by Ellen Kennedy. Cambridge, MA: MIT Press.

—_. (1932) 2004. Legality and Legitimacy. Translated by Jeffrey Seitzer. Durham, NC: Duke University Press.

Scott, James. 1998. Seeing Like a State: How Certain Schemes to Improve the Human Condition Have Failed. New Haven, CT: Yale University Press.

Shore, Cris, Susan Wright, and Davide Però, eds. 2011. Policy Worlds: Anthropology and the Analysis of Contemporary Power. Oxford: Berghahn Books.

Steinmetz, George. 2014. "On Bourdieu, Sur l'État: Field Theory and the State, Colonies, and Empires." Review of On the State. Lectures at the Collège de France 1989-1992. Sociologica 8 (3): 1-13.

Tu, Weiming. 1996. "Cultural Identity and the Politics of Recognition in Contemporary Taiwan." China Quarterly, no. 148, 1115-140.

Weber, Max. 1978. Economy and Society: An Outline of Interpretive Sociology, edited by Guenther Roth and Claus Wittich. Berkeley: University of California Press.

Weller, Robert P. 1999. Alternate Civilities: Democracy and Culture in China and Taiwan. Boulder CO: Westview Press.

Winn, Jane Kaufman. 1994. "Relational Practices and the Marginalization of Law: Informal Financial Practices of Small Businesses in Taiwan.” Law and Society Review 28 (2): 193232.

Wolf, Margery. 1968. The House of Lim: A Study of a Chinese Farm Family. New York: Appleton-Century-Crofts. 
Woolard, Kathryn A. 1999. "Simultaneity and Bivalency as Strategies in Bilingualism." Journal of Linguisitic Anthropology 8 (1): 3-29.

Young, Russell L., Shuan-fan Huang, Alberto Ochoa, and Natalie Kuhlman. 1992. "Language Attitudes in Taiwan." International Journal of the Sociology of Language, no. 98, 5-14. 